\title{
Is Using Biogas Fuel More Profitable for Rural Communities in Yogyakarta?
}

\author{
Dessy Rachmawatie ${ }^{1, *}, \mathrm{Nuva}^{2}$, Eko Priyo Purnomo ${ }^{3,4}$ \\ ${ }^{1}$ Department of Economics, Universitas Muhammadiyah Yogyakarta, Yogyakarta \\ ${ }^{2}$ Department of Resource and Environmental, IPB University, 16680 Bogor, Indonesia \\ ${ }^{3}$ Department of Government Public and Administration,Universitas Muhammadiyah Yogyakarta, 55183 Yogyakarta, Indonesia \\ ${ }^{4}$ E-Governance and Sustainability Institute, Yogyakarta Indonesia \\ ${ }^{*}$ Corresponding author. Email: d.rachmawatie@umy.ac.id
}

\begin{abstract}
The development of biogas in community settlements is now very much needed. It is since people's uses of Liquified Petroleum Gas (LPG) are very high but are not matched by its availability. Many areas in the Special Region of Yogyakarta are starting to switch to using renewable energy, biogas, for cooking. The utilization of biogas is now not only for rural communities but has penetrated urban communities. In Cangkringan Subdistrict, Sleman, many people have switched to using biogas as a substitute for LPG. However, many farmers still have not utilized livestock manure as alternative energy, namely biogas. In reality, many of the reasons people have not used livestock manure for alternative energy are due to a lack of knowledge about biogas. Besides, the beginning of biogas production starts in rural areas as, in rural settlements, many breeders have livestock, and rural areas are appropriate for farmers to raise livestock to plow fields. Lastly, urban areas have vital areas where biogas utilization is very difficult. Nevertheless, many apartments and even large companies have now switched to using alternative energy such as solar cells and even biogas.
\end{abstract}

Keywords: Biogas, Development, Rural, Communities.

\section{INTRODUCTION}

This study aims to determine the sustainability of bioenergy-biogas development by identifying sustainability indicators and evaluation criteria. The research focuses on planning strategic mapping of potential areas of the agricultural sector as a source of bioenergy and then analyzing institutions in determining potential areas for downstream agriculture development in the utilization of superior renewable energy comparatively and competitively.

In order to fulfill household energy needs, especially in rural areas, it is necessary to make systematic efforts to implement various feasible energy alternatives for the community. In connection with this, one of the breakthrough efforts made is to carry out an outreach and training program on the use of household-scale biogas as an environmentally friendly alternative energy source. [1]

Furthermore, the use of renewable energy has many benefits, including ecological benefits, economic benefits, energy security benefits and ensuring the existence of natural resources. The development of renewable energy in rural areas, such as rural bioenergy, is an implementation of government policies issued since 2006 to be an alternative to meet household energy needs, especially for rural areas.
Rural bioenergy-biogas development is one of the many utilization and development of new and renewable energy, which has been massively developed in the last two decades in six provinces in Indonesia, including West Java, Central Java, Special Region of Yogyakarta, Bali, Central Nusa Tenggara, and Maluku and five districts/cities, namely Kapuas, North Kolaka, Biak, Polewali Mandar, and Barru.

The research began with a literature study related to the sustainability of bioenergy-biogas, both in terms of the sustainability of power plant operations and development sustainability, to identify sustainability indicators and evaluation criteria. Expert judgment in this research was then needed to validate a set of sustainability indicators and evaluation criteria.

The scope of this research is to recognize the sustainability and development of bioenergy-biogas by determining indicators and evaluation criteria. The research focuses on the strategic planning of potential agricultural and plantation areas in the Special Region of Yogyakarta Province as a potential area for bioenergy sources. Subsequently, institutional analysis was carried out on areas potential to be developed by the downstream agricultural and livestock sectors in Yogyakarta to utilize comparatively and competitively renewable energy. 


\section{LITERATURE REVIEW}

\subsection{Rural Development}

A village is a legal community unit with territorial boundaries to regulate and manage government affairs and local community interests based on community initiatives, origin rights, and traditional rights [2]. Those are recognized and respected in the government system of the unitary state of the Republic of Indonesia. Meanwhile, according to Seers, development means the conditions for the realization of the human personality. Therefore, its evaluation must consider three linked criteria: where there has been a reduction in poverty, unemployment, and inequality.

Rural development means a social and economic activity to increase the concept of retention, growth, and expansion outside of urban areas to improve rural people's quality of life [3]. Currently, there are rural problems in Indonesia, covering incompetent government agency, low levels of community participation in rural development, less productive human resources, conversion of agricultural land, disasters, lack of rural development funds, and lack of employment opportunities. As a result, many rural people are urbanizing.

The driver of rural development in Indonesia is the only main party. First, the individual or group has ideas and initiatives to develop the village. Second, the government issues a program to build the village. Rural development must also pay attention to the potential of village resources, the direction of development, and the management of village resources.

\subsection{Sustainable Development}

The term sustainable development was published in 1987 by the Brundtland Commission, Norway, in a report entitled "Our Common Future." The main goal of sustainable development is a long-term relationship between the economy and the environment [4]. Development needs must pay attention to the long-term benefits for the next generation's needs. In addition, a new agreement among nations to actualize joint sustainable development is called the SDGs (Sustainable Development Goals). The purpose of SDGs is to create economic growth in line with environmental conservation.

Currently, Indonesia's development paradigm has changed from concentrating only on economic growth to a sustainable development paradigm [5]. Nevertheless, the environmental aspect remains a matter that must be considered in development. Indonesia's development still tends not to focus on environmental aspects. Several development indicators showed that Indonesia's development was not balanced. Much development is in the socioeconomic aspect but does not pay attention to environmental conditions [6].

\subsection{Development of Biogas Utilization in Rural Areas}

Biogas is an environmentally friendly alternative energy solution. Biogas is also easy to use, especially for rural communities that raise cattle. In connection with these problems, the utilization of waste manure can be optimized to reduce costs without disturbing livestock productivity. The advantages or added value related to the use of biogas are reducing the volume of waste disposed of, obtaining highquality fuel, and reducing methane gas emissions [7].

In Indonesia, the development of biogas began to be implemented in the early 1970s. The development aimed to utilize waste and other biomasses to find alternative energy sources other than firewood and kerosene. However, the program had not been widely developed in the community. Why is that? It is because people can still buy kerosene and LPG gas sold in the market for daily needs. Besides, the main obstacle is the relatively high cost of making biogas installations [8].

Moreover, biogas is a gas produced from the decomposition process (fermentation) of organic materials, including animal waste and other microorganisms, producing methane and carbon dioxide gas [9]. Biogas is a type of fuel converted from livestock manure processed to produce methane gas, which can be used as fuel to replace kerosene or LPG gas to meet people's daily needs [10].

Utilizing biogas as an alternative energy source can provide economic and social benefits as it is environmentally friendly. Biogas production will control and reduce livestock waste problems, but at the same time, the energy produced can be used for cooking fuel. In addition, biogas by-products (sludge) can reduce production costs [11] in agriculture and animal husbandry, namely as fertilizer and feed ingredients. Biogas production from agricultural and livestock waste has been carried out with many kinds of digester devices, but its use on a household scale needs to be explored further. The costs required for biogas production must also be able to provide economic benefits, so it is necessary to know that the feasibility aspect is good [12].

The main installation of biogas is a digester (reactor) that functions as a shelter for livestock manure, producing methane gas from the conversion of organic materials by bacteria [13]. To make a digester, the following materials are needed: sand, cement, river stone, coral, red stone, construction iron, paint, and Parallon pipes to connect the gas stored in the digester installation to the biogas stove. For the digester itself, the construction site should be close to the cattle pens so that it is easier for livestock manure to be directly channeled into the digester. In addition to building a digester, a slurry shelter (mud) must also be built where the slurry will settle and be separated; later, the sediment will be used as solid/liquid organic fertilizer [14].

The benefits of biogas can be used to save household expenses so that household needs can be met at a relatively low cost. This biogas can also help the state reduce the state 
budget for imports of fuel oil from abroad [15]. Utilization of animal manure waste as raw material for biogas energy can minimize problems resulting from the remaining manure compared to just being left to accumulate without any special handling/processing. Livestock manure that accumulates will have a negative impact on the environment, including air pollution. It is produced from piles of left-untreated livestock manure, which causes unpleasant odors around the livestock environment and can cause a greenhouse effect. It happens because the methane gas that comes out of the livestock manure cannot be decomposed. In addition, the utilization of livestock manure can help development in agriculture by using the remaining manure that has been processed into organic fertilizer for farmers. Not only for cooking needs but biogas as alternative energy can also produce electricity [16]. The processing/utilization of livestock manure as alternative energy also provides enormous benefits since it can utilize natural sources without destroying their habitat to maintain the ecological cycle [17].

\subsection{Biogas Sustainability Model}

In the past, biogas was discovered by the Chinese in the form of a gas mixture in a swamp called methane gas swamp. The fermentation process to form methane gas was first discovered by Alessandro Volta in 1778. In 1896, the first anaerobic digester was built in England. Biogas was used by British farmers during World War II to drive tractors. However, its use began to be abandoned along with the discovery of fuel in large quantities and low prices. Biogas technology is also developing in countries in Africa, Europe, China, and India. In 1920, China's first methane company was founded. In Indonesia, biogas began to develop around 1970. However, the high level of fuel oil caused the use of biogas to become less developed [18]. Biogas technology began to develop again in 2006 when fuel prices rose; government subsidy policies and energy scarcity became the main topics in Indonesia. Initially, the government built biogas as a demonstration plot with a floating actor made of connected drums. Now, the reactor materials used have developed; some are made of concrete, plastic, and glass fiber. This increasingly practical biogas technology can increase the potential for using biogas as an alternative energy source [19].

Now, biogas has begun to be developed to be used as alternative energy to replace fuel. Public awareness of the fulfillment of sustainable energy sources makes biogas the right choice, especially for people in rural areas [20]. The reason is that rural communities usually have livestock whose waste can be utilized to reduce environmental pollution and save household expenses. People who work as farmers can also run an integrated farming program through biogas technology by utilizing the biogas output in the form of organic fertilizer. The organic fertilizer produced also has excellent quality and is ready to use. These efforts can reduce the use of chemical fertilizers to support the creation of organic agriculture, whose products are currently in great demand [21].
Biogas energy has the potential to be developed. Some of the reasons [22] are:

1. The production of biogas from cow manure has been supported by conducive conditions for developing cattle farming in Indonesia.

2. Regulations in the energy sector, such as increasing electricity rates, increasing prices for LPG (liquefied petroleum gas), premium diesel oil, diesel oil, and fuel oil, have encouraged the development of cheap, sustainable, and environmentally friendly alternative energy sources.

3. The increase in prices and the scarcity of organic fertilizers in the market due to poor marketing distribution causes farmers to turn to the use of organic fertilizers.

4. Reducing the effect of greenhouse gases, reducing unpleasant odors, and preventing the spread of disease

5. Applying the concept of zero waste agriculture that is environmentally friendly and sustainable

\section{METHOD}

\subsection{Research Location}

This research was conducted in the Special Region of Yogyakarta (DIY) Province. The location selection was done deliberately, considering that this research was carried out based on the business of developing biogas made from livestock manure. The location was chosen due to the large number of livestock and livestock waste that had not been properly processed.

\subsection{Sampling/Respondent Method}

The respondents in this study consisted of 1. The villagers of Gunung Kidul, Yogyakarta, especially farmers 2. The researchers worked together to get data or samples from government agencies in accordance with this research, namely the biogas energy sector.

\subsection{Methods, Data Types, and Data Collection Techniques}

The collecting data method in this research was divided into primary and secondary data collection. Primary data were obtained and put together directly by the researchers from the ongoing research results to produce a problem formulation or purpose of research conducted through observation, interviews, discussions, and questionnaires. Meanwhile, secondary data are obtained and made by an external party. In this study, the secondary data were obtained from institutions or previous research, such as the Central Statistics Agency, the Ministry of Energy and Mineral Resources, and the DIY Province monograph. The types of data used in the secondary data in this study were the population of cows, the number of biogas generators from cow dung, and other data needed to support the research. 


\section{RESULTS AND DISCUSSION}

Bioenergy is the energy obtained from biological organisms or organic matter. Bioenergy generally produces three types of energy sources: biofuels (biodiesel, bioethanol), biogas, and solid biomass (wood chips, bio briquettes, and agricultural residues). Bioenergy can also produce three forms of energy: electricity, transportation fuels, and heat. Bioenergy is expected to replace the important role of fossil energy sources, which are non-renewable energy sources [23]. In the last decade, bioenergy has become an essential topic in Indonesia. There are at least four factors that encourage the development of the bioenergy sector. First, bioenergy is seen as a solution to the problem of energy security [24]. National oil production reached its highest level in the decade of the 2000s but is expected to decline until 2025. This situation indicates a threat to national energy security. To overcome the energy security problem, Indonesia has increased import oil since 2007 and is expected to continue to increase until 2025 [25]. In this case, alternative energy in the form of bioenergy as new renewable energy is one solution to reduce import pressures and overcome energy security threats [26].

Second, Indonesia's efforts to produce bioenergy are driven by the motivation to utilize clean energy to respond to concerns about the adverse effects of greenhouse gas (GHG) emissions from the use of fossil energy. Bioenergy cannot be said to be clean energy because it is related to production processes that are still not fully sustainable. However, bioenergy is still seen as an energy that is more environmentally friendly than fossil energy since this energy is produced by agricultural production activities. In turn, carbon emissions produced by burning bioenergy can be reabsorbed into the carbon cycle system of agricultural activities [27]. Third, bioenergy development can be used as an instrument for controlling commodity prices, including agricultural commodities [28]. In this case, the development of palm-based biodiesel in Indonesia is one of the measures to control palm oil supply to the global market, which is expected to boost international palm oil prices and revitalize the palm oil sector in Indonesia. Fourth, bioenergy is also a solution to encourage local, regional, and national economies through agricultural development. The demand for bioenergy raw materials will encourage an increase in biomass production from domestic resources, which in turn will encourage the growth of the bioenergy industry, expansion of employment opportunities, increased state revenues, and economic growth [29].

One of the sources of bioenergy is biogas. Biogas is an important renewable energy source and can be used as alternative energy to replace fossil energy sources, such as oil and natural gas. Biogas is produced from the process of breaking down organic waste materials, which involves the activity of anaerobic bacteria under anaerobic conditions in a digester. The main compositions of biogas are methane (CH4), Carbon dioxide (CO2), Hydrogen (H2) and Hydrogen Sulfide (H2S). Biogas is also environmentally friendly energy as it does not produce smoke, and the waste contains elements needed by plants. For this reason, this study aims to develop the potential of organic waste and trigger an increase in livestock production in the Monggol Village area, Gunungkidul Regency, Special Region of Yogyakarta. This research was conducted in the Mongol Village because of the potential for organic waste in the area in the form of cattle farm waste, which has not been utilized optimally until now.

\subsection{General Description of Research}

\subsubsection{Gunung Kidul Regency}

The location of this research is in Gunungkidul, Kulonprogo, Bantul and Sleman Regencies. Rejosari Village is one of the villages in Semin Subdistrict, Gunungkidul Regency, located far from the city center of Yogyakarta province, about $70 \mathrm{KM}$. Rejosari Village has a limestone hill topography with a solid or immovable soil structure (liquefaction). It is because Rejosari Village is squeezed by limestone hills that are still sturdy. The hamlets in Rejosari Village are such as Bedil Wetan, Ngerco, Sempu Kidul, Sempu Lor, Ngadipiro Lor, Kaligayam Lor and Karangpilang Kidul, Josari, Kaligayam Kidul, Karangpilang Lor, and Ngadipiro Kidul. The annual threat that always attacks the Rejosari Village is the drought since the Rejosari Village has difficulty finding water sources for consumption and agriculture. With 11 hamlets, the number of RT (Neighborhood Association) is 22, and the number of RW (Citizens Association) is 11, with a total population of 5,479 people.

In addition, Rejosari Village is one of the closest villages to the Wonogiri area, more precisely near Gajah Mungkur reservoir. Already known for its dry area and lack of water sources, residents have made many efforts to make water reservoirs, but the water availability in Rejosari Village is minimal. It is also caused by the condition of the limestone mountains, whose springs are very deep and can even reach tens of meters to find the water source. There are water reservoirs in every hamlet, but there are very few of them.

Most of the people in Rejosari Village are farmers and ranchers. The rice fields in Rejosari Village are fertile, but many of the residents' agricultural land has failed to harvest because of the drought. Community harvested commodities are such as rice, secondary crops, cassava, and corn. Besides, every farmer in Rejosari Village must have a minimum of cattle because it is not only used for empowering cow dung waste as biogas but also for helping farmers to plow the fields. However, some farm animals are also sold as a business or reduce the farmers' pens population.

Further, biogas development in Rejosari Village was mostly in Ngerco and Sempu Kidul hamlets with 37 family heads who were still actively developing biogas. There were even respondents who used biogas to open a new business such as a food business. However, there were many obstacles in developing biogas in the field, such as the local community that had not been able to adapt to the operation and maintenance of the digester due to busy activities other than 
biogas development in the hamlet. It can be proven by the researchers observing many voids in the digester. Besides, each biogas user had one digester and biogas development in the Garotan hamlet area through a vendor named Biru. However, the sustainable use of biogas in Garotan Hamlet still needs much attention in the future. It is due to the lack of awareness of the local community with efforts to develop biogas that is beneficial for the local village community.

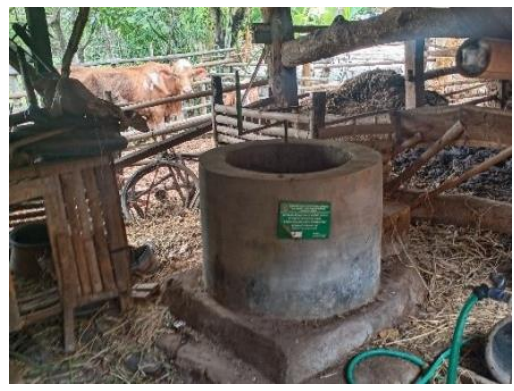

Figure 1. Cow Manure Processing Site in Rejosari Village

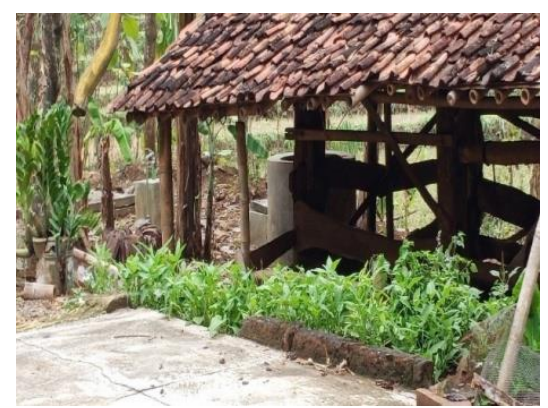

Figure 2. Cattle Breeding in Rejosari Village

\subsubsection{Bantul Regency}

Gilangharjo Village, in general, is a village with a typology of rice fields. Meanwhile, some hamlets do have clay soil types, but they are generally still productive for agriculture and gardening.

Gilangharjo is also one of the villages in Pandak District, Bantul, Yogyakarta Special Region, Indonesia. This village has an area of \pm 726 hectares, consisting of 15 Hamlets and 91 RT. The population of Gilangharjo Village in 2017 was 17,025 people consisting of 5,500 families. The people of Gilangharjo Village generally farm and raise livestock. There are many livestock farms in the Gilangharjo Village area, but what stood out in 2010 was the 1,534 cattle farms spread over 15 hamlets that already had group cages.

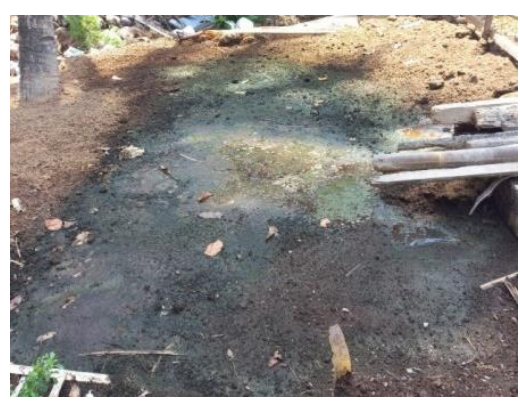

Figure 3. Wet Fertilizer Final Result

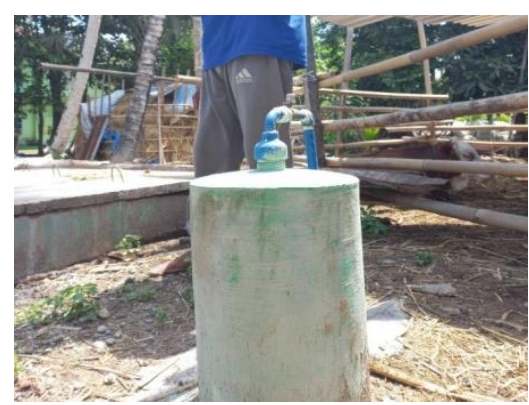

Figure 4. Processing Outgoing and Incoming Control Tool

\subsubsection{Sleman Regency}

The location of this research was carried out in Hargobinangun Village, Pakem District, Sleman Regency. To get to Hargobinangun Village, it took one hour. The road conditions toward Hargobinangun Village were fairly good, and there were no problems. In this study, most respondents were over 30 years old and had a livelihood as breeders, farmers, and sellers of dairy cows' milk. Respondents received assistance for biogas development from the Sleman Office. Several respondents received biogas development from the Gajah Mada University student program. The biogas development in Hargobinangun Village was individual, so there was no group leader. However, the obstacle faced by respondents was the high cost of maintenance. Besides, the tools used in Sleman Regency were quite easy to use because they were not stirred manually; the channels were also directly connected.

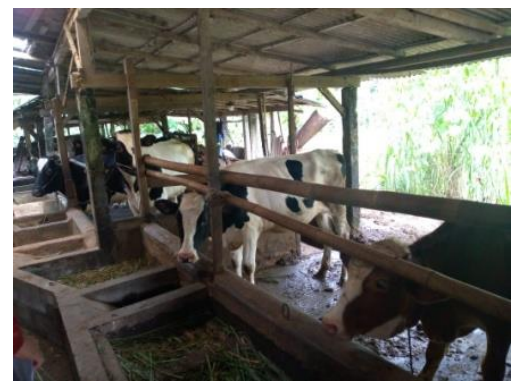

Figure 5. Cattle Breeding in Hargobinangun Village

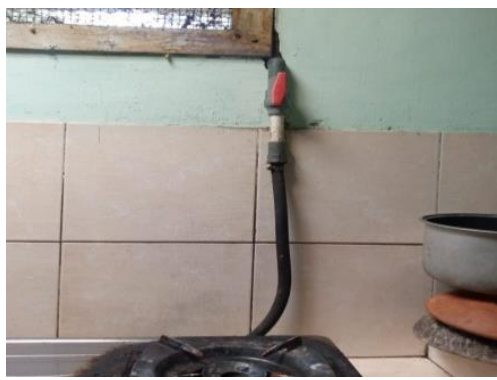

Figure 6. Connecting Line to Gas in Hargobinangun Village

\subsubsection{Kulonprogo Regency}

The location of this research is in Sidoharjo Village, Samigaluh District, KulonProgo Regency, which consists of the hamlets of Munggang Wetan, Madigondo, Gorolangu, Munggang Lor, and Sumoroto. The location of the area in 
KulonProgo took approximately one hour to reach the Samigaluh sub-district. The roads there went up and down; some have been already asphalted, but some were still in the form of clay/not asphalted.

The majority of the respondents were over 30 years old and had a livelihood as ranchers, farmers, and freelancers. Respondents received assistance for biogas development from a program organized by Mr. Budi as the Regional Representative Council of Samigaluh. For biogas development in the Samigaluh sub-district, it was individual, so there was no group leader. However, a technician, Mr. Caroko, also directed and provided outreach to the biogas developers there.

Nevertheless, constraints faced by respondents included the high maintenance costs and the manual biogas technology used, namely by stirring.

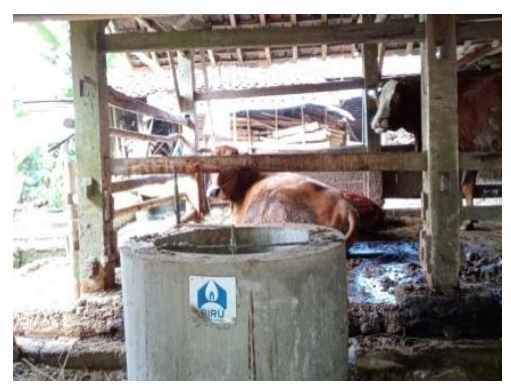

Figure 7. Cattle Breeding in Sidoharjo Village

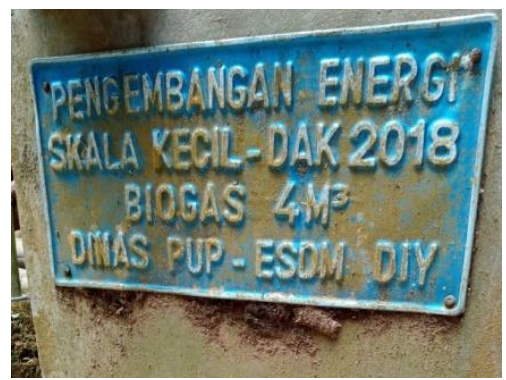

Figure 8. The scale of Small Energy Development

\subsection{Economic Analysis}

By developing biogas in the villages in Gunungkidul, Bantul, Sleman, and Kulonprogo Regency, it will increase the welfare of the residents because with the presence of biogas, residents do not need to buy LPG gas. For fertilizer needs, they can also be met because the waste produced from biogas is a liquid fertilizer that can be directly applied to plants to reduce the need for chemical fertilizer.

Economic prospects that can be generated:

\subsubsection{The analysis scenario if using Ipg gas:}

1 gas cylinder of $3 \mathrm{~kg}$ IDR 20,000 for 5 days

$$
\begin{aligned}
& 30 \text { days }=\text { IDR } 20,000 \times 6=\operatorname{IDR} 120,000 \\
& 1 \text { year }=\text { IDR } 120,000 \times 12=\operatorname{IDR} 1,440,000
\end{aligned}
$$

\subsubsection{The analysis scenario if using biogas:}

Cost of making biogas IDR 2,500,000

Sufficient gas supply throughout the year

Potential Liquid Fertilizer 20 L every day

Potential liquid fertilizer in 1 year 365 x $20 \mathrm{~L}=7,300 \mathrm{~L}$

The selling price of liquid fertilizer in $1 \mathrm{~L}$ is IDR 1,000 .

Thus, for example, assuming that all the liquid fertilizer waste will be sold in a year, it will earn IDR 7,300,000. Thus, in 1 year, the cost of making biogas can be covered and make a profit with the availability of biogas for one year and the sale of liquid fertilizer. With this huge potential, making biogas installations can increase residents' income and improve the welfare of the rural community. In addition, the biogas problem arising when new biogas is produced is the composition of the biogas itself since biogas contains several other not profitable gases.

\section{CONCLUSION}

The development of biogas in community settlements is now very much needed. It is since people's uses of Liquified Petroleum Gas (LPG) are very high but are not matched by its availability. Many areas in the Special Region of Yogyakarta are starting to switch to using renewable energy, biogas, for cooking. The utilization of biogas is now not only for rural communities but has penetrated urban communities. The cost of making biogas can be covered and make a profit with the availability of biogas for one year and the sale of liquid fertilizer. With this huge potential, making biogas installations can increase residents' income and improve the welfare of the rural community. In addition, the biogas problem arising when new biogas is produced is the composition of the biogas itself since biogas contains several other not profitable gases.

\section{ACKNOWLEDGMENTS}

Thank you to the Research Innovation Institute, University of Muhammadiyah Yogyakarta, which has provided an internal grant for applied research in 2021 and contributed to the successful implementation of this research.

\section{REFERENCES}

[1] Bunganaen, W., \& Adoe, D. (2021). Pemanfaatan biogas untuk kemandirian energi pedesaan 1,2). Jurnal Pengabdian Kepada Masyarakat Undana, 15(1), 51-54. http://ejurnal.undana.ac.id/index.php/jlppm/article/view/4888

[2] Dhliwayo, N., Chanza, N., \& de Wit, A. (2020). Beyond climatic intervention: The social dimension of a biogas project in Sogwala village, Zimbabwe. Journal of Energy in Southern Africa, 31(4), 43-56. https://doi.org/10.17159/24133051/2020/v31i4a8924

[3] Evgrafova, L. V., Ismailova, A. Z., \& Kalinichev, V. L. (2020). Agrotourism as a factor of sustainable rural development. IOP Conference Series: Earth and 
Environmental Science, 421(2). https://doi.org/10.1088/1755$1315 / 421 / 2 / 022058$

[4] Mordeson, J. N., \& Mathew, S. (2020). Sustainable goals in combating human trafficking: Analysis by mathematics of uncertainty. Journal of Algebraic Hyperstructures and Logical Algebras, 1(1), 49-59. https://doi.org/10.29252/hatef.jahla.1.1.4

[5] Amien, D. Al, Setyani, F. D., \& Sihombing, R. (2020). Sustainable Port Planning in Future Indonesian Ports: A Case Study of Mafa Port based on un SDGs. IOP Conference Series: Earth and Environmental Science, 618(1). https://doi.org/10.1088/1755-1315/618/1/012041

[6] Hilman, I., Hendriawan, N., Nurulhuda, D., \& Purwani, O. (2021). Identifying the sustainability level of urban slums in the Greater Jakarta, Indonesia using a composite index Identifying the sustainability level of urban slums in the Greater Jakarta, Indonesia using a composite index. IOP Conference Series: Earth and Environmental Science. https://doi.org/10.1088/1755-1315/824/1/012093

[7] Morero, B., Groppelli, E., \& Campanella, E. A. (2015). Life cycle assessment of biomethane use in Argentina. Bioresource Technology, 182(January), 208-216. https://doi.org/10.1016/j.biortech.2015.01.077

[8] Fathurrohman, A., Aniar Hari S, M., \& Awaludin Adam, M. (2015). Persepsi peternak sapi dalam pemanfaatan kotoran sapi menjadi bi-ogas di Desa Sekarmojo Purwosari Pasuruan. Jurnal Ilmu-Ilmu Peternakan, 25(2), 36-42. https://doi.org/10.21776/ub.jiip.2015.025.02.05

[9] Polishchuk, V. M., Shvorov, S. A., Tarasenko, S. Y., \& Antypov, I. O. (2020). Increasing the biogas release during the cattle manure fermentation by means of rational addition of substandard flour as a cosubstrate. Science and Innovation, 16(4), 23-33. https://doi.org/10.15407/scine16.04.023

[10] Semin, Fathallah, A. Z. M., Cahyono, B., Ariana, I. M., \& Sutikno. (2014). Kajian Pemanfaatan Kotoran Sapi Sebagai Bahan Bakar Biogas Murah Dan Terbarukan Untuk Rumah Tangga Di Boyolali. Jurnal Sains, Teknologi Dan Industri, 11(2), 212-220. https://doi.org/DOI: http://dx.doi.org/10.24014/sitekin.v11i2.749

[11] Almomani, F. (2020). Prediction of biogas production from chemically treated co-digested agricultural waste using artificial neural network. Fuel Length Article, 280(June), 118573. https://doi.org/10.1016/j.fuel.2020.118573

[12] Walowski, G. (2021). Development of biogas and biorafinery systems in Polish rural communities. Journal of Water and Land Development, 49, 156-168. https://doi.org/10.24425/jwld.2021.137108

[13] Setyobudi, R. H., Yandri, E., Fayiz, M., Atoum, M., Adinurani, G., Vincēviča, Z., Widodo, W., \& Zalizar, L. (2021). Healthy-Smart Concept as Standard Design of Kitchen Waste Biogas Digester for Urban Households. Jordan Journal of Biological Sciences, 14(September), 613-620.

[14] Silaen, M., Taylor, R., Bößner, S., Anger-kraavi, A., Chewpreecha, U., Badinotti, A., \& Takama, T. (2020). Lessons from Bali for small-scale biogas development in Indonesia. Environmental Innovation and Societal Transitions, 35(25), 445-459. https://doi.org/10.1016/j.eist.2019.09.003

[15] Ngo, T., Ball, A. S., \& Shahsavari, E. (2021). The Current Status, Potential Benefits and Future Prospects of the Australian Biogas Sector. Journal of Sustainable Bioenergy Systems, $\quad 11(01)$,

$14-32$. https://doi.org/10.4236/jsbs.2021.111002

[16] Geddafa, T., Melka, Y., \& Sime, G. (2021). Determinants of Biogas Technology Adoption in Rural Households of Aleta Wondo District, Sidama Zone, Southern Ethiopia. Journal of
Energy,

https://doi.org/https://doi.org/10.1155/2021/9934942

[17] Khan, M. U., Ahmad, M., Sultan, M., Sohoo, I., Ghimire, P. C., Zahid, A., Sarwar, A., Farooq, M., Sajjad, U., Abdeshahian, P., \& Yousaf, M. (2021). Biogas production potential from livestock manure in Pakistan. Journal of Sustainability, 13(12), https://doi.org/10.3390/su13126751

[18] Hilda, L., Lubis, R., \& Replita. (2021). Biogas : Renewable Energy. IOP Conference Series: Materials Science and Engineering, 1156(1), 012013. https://doi.org/10.1088/1757$899 x / 1156 / 1 / 012013$

[19] Wang, Z., Ali, S., Akbar, A., \& Rasool, F. (2020). Determining the influencing factors of biogas technology adoption intention in Pakistan: The moderating role of social media. International Journal of Environmental Research and Public Health, 17(7). https://doi.org/10.3390/ijerph17072311

[20] Irawan, D., Dharmawan, A. H., \& Sumarti, T. (2020). Bioenergi Pedesaan: Solusi Konflik Sosial Ekologi dan Pembangunan Berkelanjutan. Jurnal Ilmu Lingkungan, 18(2), 247-252. https://doi.org/10.14710/jil.18.2.247-252

[21] Arifin, M. Z., Khoir, M., \& Purwanto, B. E. (2020). Community attitudes towards biogas as an alternative energy and environmental quality improvement. Journal of Physics: Conference Series, 1517(1). https://doi.org/10.1088/1742$6596 / 1517 / 1 / 012043$

[22] D'adamo, I., Morone, P., \& Huisingh, D. (2021). Bioenergy: A sustainable shift. Journal of Energies, 14(18), 2-5. https://doi.org/10.3390/en14185661

[23] Kung, C., Lee, T., \& Chen, L. (2021). Economic growth and environmental sustainability from renewable energy applications. Journal of Energy Exploration \& Exploitation, 39(2), 531-532. https://doi.org/10.1177/0144598720964207

[24] Silaen, M., Taylor, R., Bößner, S., Anger-kraavi, A., Chewpreecha, U., Badinotti, A., \& Takama, T. (2020). Lessons from Bali for small-scale biogas development in Indonesia. Environmental Innovation and Societal Transitions, 35(25), 445-459. https://doi.org/10.1016/j.eist.2019.09.003

[25] Prabowo, Y., Broto, S., Nazori AZ, Sujono, Musafa, A., Peby, Wisjnuadji, T., \& Siswanto. (2020). JAM-TEKNO Pemberdayaan Masyarakat Pada Pembuatan Blender Sampah Untuk. Jurnal Pengabdian Kepada Masyarakat TEKNO, 1(2), $1-6$.

[26] Lowitzsch, J., Hoicka, C. E., \& van Tulder, F. J. (2020). Renewable energy communities under the 2019 European Clean Energy Package - Governance model for the energy clusters of the future? Renewable and Sustainable Energy Reviews, 122(October 2019), 109489. https://doi.org/10.1016/j.rser.2019.109489

[27] Ostergaard, P. A., Johannsen, R. M., \& Duic, N. (2020). Sustainable development using renewable energy systems. International Journal of Sustainable Energy Planning and Management, 29, 1-6. https://doi.org/10.5278/ijsepm.4302

[28] Salleh, S. F., Mohd Roslan, M. E., Abd Rahman, A., Shamsuddin, A. H., Tuan Abdullah, T. A. R., \& Sovacool, B. K. (2020). Transitioning to a sustainable development framework for bioenergy in Malaysia: policy suggestions to catalyse the utilisation of palm oil mill residues. Energy, Sustainability and Society, 10(1), 1-20. https://doi.org/10.1186/s13705-020-00269-y

[29] Alsaleh, M., Abdulwakil, M. M., \& Abdul-Rahim, A. S. (2021). Does social businesses development affect bioenergy industry growth under the pathway of sustainable development? Sustainability (Switzerland), 13(4), 1-19. https://doi.org/10.3390/su13041989 